\title{
Women Fertility Decision using the Count Model in Malaysia
}

\author{
Rohana Kamaruddin ${ }^{1}$ \\ ${ }^{1}$ Centre of Economics and Financial Studies, Faculty of Business Management, Universiti Teknologi MARA, \\ Shah Alam, Selangor, Malaysia \\ Correspondence: Rohana Kamaruddin, Faculty of Business Management, Universiti Teknologi MARA, Shah \\ Alam, Selangor, Malaysia. Tel: 603-5544-3306. E-mail: rohana070@salam.uitm.edu.my
}

Received: May 17, 2017 Accepted: June 30, 2017 Online Published: August 3, 2017

doi:10.5539/jms.v7n3p133 URL: http://doi.org/10.5539/jms.v7n3p133

\begin{abstract}
Fertility depends on household decisions in Malaysia; and, in turn, these decisions are strongly influenced by economic and socio-economic factors. Currently, fertility levels around the world vary according to the intergenerational relationships, the socio-economics statuses, and the socio-demographic characteristics of a particular nation. In general, more industrialized and economically developed societies have lower fertility than less-developed societies do. Groups that are more educated and earn higher incomes have lower fertility than less-educated groups with lower incomes do. The purpose of this paper is to dicuss the development of the empirical model to identify the principal determinants of fertility in Malaysia. The results stemmed from the use of panel data that is obtained from the Minnesota Population Centre, the Integrated Public Use Microdata Series, and international data provided by the Department of Statistics, Malaysia. In the empirical analysis, count models are employed. The findings show that marital status, owning a house, and households having women of child-bearing age all affect fertility decisions. In addition, social characteristics, such as ethnicity, religion, socio-economic status, and education level, affect household's fertility decision.
\end{abstract}

Keywords: fertility, household, socioeconomics, demographics, population

\section{Introduction}

Malaysia had a population of a 28.6 million, in 2010. This figure is projected to increase by between 10 million (35\%) and 38.6 million (42.5\%) in 2040. Malaysia's population is famously diverse, and this diversity has been strongly influenced by both the history of and future outlook for the country's population. Malaysia is home to three major ethnic groups, namely the Bumiputera (includes Malays and Indigenous), Chinese, Indians, others and non-Malaysian. Before independence (1957), the Malaysian demographic situation was one of a high natural population growth of $6.3 \%$. Between 1958 and 1978, the total fertility rate (TFR) fell from 6.3 births per woman to 4.0 births, with all the principal ethnic groups (Chinese, Indians, and Malays) registering fertility declines. During this period, the fertility rate for Malays was 2.8 children per woman, for the Chinese, 1.8 children per woman, and for the Malaysian Indian population, 2.0 children per woman. Presently, Malay fertility rates are $40 \%$ higher than that of Malaysian Indians and 56\% higher than that of Malaysian Chinese. In 2010, the total Malaysian population consisted of $60 \%$ Malays, $22.9 \%$ Chinese, and $7.1 \%$ Indians. Based on the latest data, the fertility rate in Malaysia has declined from 3.00 in 2000 to 2.2 in 2010 (Table 1).

Table 1. Fertility rate in Malaysia: 2000-2010

\begin{tabular}{llllllllllll}
\hline Year & 2000 & 2001 & 2002 & 2003 & 2004 & 2005 & 2006 & 2007 & 2008 & 2009 & 2010 \\
\hline Y & 3.0 & 2.8 & 2.6 & 2.5 & 2.4 & 2.4 & 2.3 & 2.3 & 2.3 & 2.3 & 2.2 \\
\hline
\end{tabular}

Source: Department of Statistic Malaysia (updated 18/1/2013).

Table 2 presents the historic, present, and future (projected) population growth rates by ethnic group for the period 2010 to 2040 . The differences in these figures across groups are due to differences in fertility, mortality, and migration rates. The data shows reductions in the annual growth rates for the Chinese and Indian groups for the thirty-year period shown in the table. 
Table 2. Average annual population growth rate by ethnic group, Malaysia, 2010-2040

\begin{tabular}{lllllll}
\hline Year & Malay & Other Bumiputera & Chinese & Indian & Others & Non Malaysian \\
\hline $2010-2015$ & 1.55 & 1.81 & 0.65 & 0.89 & 2.84 & 0.78 \\
$2015-2020$ & 1.54 & 1.73 & 0.55 & 0.82 & 2.71 & 0.63 \\
$2020-2025$ & 1.42 & 1.59 & 0.39 & 0.67 & 2.53 & 0.37 \\
$2025-2030$ & 1.23 & 1.39 & 0.23 & 0.48 & 2.30 & 0.36 \\
$2030-2035$ & 1.00 & 1.17 & 0.12 & 0.25 & 2.12 & 0.42 \\
$2035-2040$ & 0.79 & 0.95 & 0.04 & 0.08 & 1.94 & 0.41 \\
\hline
\end{tabular}

Source: Department of Statistic Malaysia (updated 18/1/2013).

The Malaysian government has introduced policies designed to improve this demographic performance as it sees a direct link between population and human capital development. Recognising that the family is the primary determinant of a healthy, dynamic, productive and competitive nation, the Government through the Ministry of Women, Family and Community Development (MWFCD) took the initiative to formulate a National Family Policy (NFP). Indirectly, the NFP acts as a provider of human resource with moral integrity through the strengthening of the family institution. These policies are intended to act positively on the majority of the country's social parameters, with the aims to develop prosperous, healthy and resilient families to ensure social stability. Under Malaysia's Sixth Development Plan (1991-1995), a comprehensive family planning program was formulated to educate the public on the practice of fertility control and also to address the issue of Malaysia's declining fertility rate. Table 3 presents the fertility rate from the period 1991-2001. The data shows a consistent rate of fertility and start declining in 1997 to 2001. These periods also marked the start of Asian financial crisis.

Table 3. Fertility rate in Malaysia: 1990-2001

\begin{tabular}{llllllllllll}
\hline Year & 1991 & 1992 & 1993 & 1994 & 1995 & 1996 & 1997 & 1998 & 1999 & 2000 & 2001 \\
\hline Percentage & 3.4 & 3.5 & 3.5 & 3.4 & 3.3 & 3.2 & 3.1 & 3 & 2.9 & 2.9 & 2.7 \\
\hline
\end{tabular}

Source: Department of Statistic Malaysia (updated 18/1/2015).

The purpose of this paper is to identify the determinants of women fertility decisions, in Malaysia, for the period 1990 to 2001. The research problem is to identify any regularity that underlies the fertility decision during the demographic transition process and which factors that contribute the most to the process.

The research questions of the study are specified as follows:

(i) What are the determinants of women fertility decision in term of socio demographics and socio-economics background?

(ii) Which factors of intergenerational effect, relative income effect, opportunity cost contributes to the fertility decision making?

An increase in women's economy activity, women's high educational attainment, late marriage, childcare and education expenses, changing valuation of children, household income and the instability of employment status and residence are important factors contributing to the declining fertility rate (Ermisch, 1988, 1989; Caldwell \& McDonald, 2002). Many studies have indicated that as women become more socially active, they are less inclined to have a baby directly after marriage (Shapiro \& Mott, 1994). However, other studies in European countries have indicated that countries with relatively high levels of women's social participation have correspondingly higher level of fertility (Del Boca, 2003). In the empirical estimation, household fertility decisions, intergenerational relationships, socio-economics factors and demographic behaviors all contribute to fertility decisions. The study's result has the potential to reveal pattern in household's preferences for deciding fertility. This may allow practitioners and policymakers to prioritize the benefits of child care allowances and preparations for the upcoming generations. The remainder of this paper is organized as follows: Section 2 presents the literature review. Section 3 provides the methodology and data. The results and discussion are presented in Section 4, and Section 5 concludes the paper.

\section{Literature Review}

A modern family prefers to have fewer children as there is a common belief that parents of small families are able to provide each child with a better life. Becker (1960) theory on this topic is the most widely discussed. Their quantity-quality model describes the increasing marginal cost of quality (child outcome) with respect to quantity (number of children), which leads to a tradeoff between the quantity and the quality of children. Morgan 
(2003) states that most countries will reach low fertility levels over the next two decades, and although this is not yet at a crisis level, this problem has become obvious in developed nations. He found that this increasing low fertility has resulted in the present slow growth of the global population. However, the main concern is the speeds at which aging populations are increasing and country-level populations are decreasing. This analysis is further supported by Lee \& Mason (2010) who describe the phenomena of low fertility in Europe and East Asia, which causes essential changes in the age structure and also declines in population growth. Herzer et al. (2010) use panel cointegration techniques to examine the long-run relationship between fertility, mortality, and income. They note that a decrease in mortality leads to a decrease in fertility and that higher incomes per capita also lead to declining fertility. They conclude that fertility is both endogenous and exogenous, such that the income-fertility interaction provides a virtual cycle of demo-economic development. As Angrist et al. (2010) explain, most scholarly empirical evidence finds that the quantity-quality trade-off comes from the negative association between family size and the schooling or academic achievement of the population. They findings on the child-quantity or child-quality trade-off analysis, using quasi-experimental variations that show twin births and preferences for a mixed sibling-sex composition including ethnic differences, prove there is no evidence of a quantity-quality trade-off. Hondroyiannis (2004) conducts an empirical study on Greece, by employing count models and using a normal distribution for the fertility decision model. Here, the empirical estimations for households are determined by using socio-economic factors for households, and controlling for specific female characteristics, such as education level, age, social status, and health status, and controlling for household-specific characteristics, such as the number of rooms in the house. The finding revealed that female characteristics such as education and number of hours working affect inversely the household decision making (increase in opportunity cost of children will decrease the number of children). Another finding directs the study to accept the women's desired number of children in Indonesia is not only affected by their lifestyle and economic preferences, but also influenced by several variables in socio-demographic, socio-economic and personal or family factors (Utomo \& Firmanto, 2007).

Fertility studies often model the number of live births over a specified age interval of the mother, while analyzing variations in terms of, say, mother's level of schooling, age, and household income (Winkelmann, 1995). Since count data can still be treated using a panel regression, the occurrence of zeros and the discrete nonnegative nature of the dependent variable suggest that, perhaps, a Poisson regression model and maximum likelihood should be used (Cameron \& Trivedi, 1998; Winkelmann, 2000). Poisson and negative binomial regression models are designed to analyze count data. However, these models differ in regard to their assumptions of the conditional mean and variance of the dependent variable. A Poisson model assumes that the conditional mean and the variance distribution are equal.

\section{Data and Methodology.}

This section explains the data and method for the study. The data is sourced from the Integrated Public Use Microdata Series (IPUMS), which is made possible by Malaysia National Statistical Offices. The data set consists of females of child-bearing age (age 18 to 49), for the years 1990 and 2001. The base-case count model used in this study includes the following variables in addition to the constant term:

NCHILD = (urban, ownrshp, poploc, momloc, marst, relig, occisco, edugroup, ethnicgroup)

The following is the description of data for the year of 1991. The unit of observation is the individual. The responses of each person to the different census questions are recorded in separate variables. 
Table 4. Variables descriptions

\begin{tabular}{|c|c|c|}
\hline Variable & Variables Description & Type/ Code \\
\hline NCHILD & $\begin{array}{l}\text { A count of the person's own children living in the household } \\
\text { with her or him. }\end{array}$ & $\begin{array}{l}\text { Household/ } \\
0,1,2,3,4,5,6,7,8,9 \text { or more }\end{array}$ \\
\hline URBAN & $\begin{array}{l}\text { URBAN indicates whether the household was located in a } \\
\text { place designated as urban or as rural. }\end{array}$ & $\begin{array}{l}\text { Household/ } \\
0 \text { - Rural } \\
1 \text { - Urban }\end{array}$ \\
\hline OWNRSHP & $\begin{array}{l}\text { OWNRSHP indicates whether a member of the household } \\
\text { owned the housing unit }\end{array}$ & $\begin{array}{l}\text { Household/ } \\
0 \text { - Owned } \\
1 \text { - Not Owned }\end{array}$ \\
\hline POPLOC/MOMLOC & $\begin{array}{l}\text { The variables indicate whether or not the person's mother or } \\
\text { father lived in the same household. }\end{array}$ & $\begin{array}{l}\text { Person } \\
0=\text { No mother/father of this person present in } \\
\text { the household. } \\
1=\text { The person number of this person's } \\
\text { mother/father }\end{array}$ \\
\hline MARST & Person's current marital status according to law or custom. & $\begin{array}{l}\text { Person/ } \\
1 \text { - single } \\
2 \text { - married } \\
3 \text { - divorced } \\
4 \text { - widowed } \\
\end{array}$ \\
\hline RELIG & Person's religion & $\begin{array}{l}\text { Person/ } \\
1 \text { - Muslim } \\
2 \text { - Buddhist } \\
3 \text { - Hindu } \\
4 \text { - Christian } \\
5 \text { - Others }\end{array}$ \\
\hline ETHNICGROUP & $\begin{array}{l}\text { The ethnic group, community, or dialect group to which the } \\
\text { person reported they belonged }\end{array}$ & $\begin{array}{l}\text { Person/ } \\
1 \text { - Malay } \\
2 \text { - Chinese } \\
3 \text { - Indian } \\
4 \text { - Others }\end{array}$ \\
\hline EDUGROUP & $\begin{array}{l}\text { The person's educational attainment in terms of the level of } \\
\text { schooling completed (degree or other milestone). }\end{array}$ & $\begin{array}{l}\text { Person/ } \\
1 \text { - Less Primary } \\
2 \text { - Primary } \\
3 \text { - Secondary } \\
4 \text { - University }\end{array}$ \\
\hline OCCISCO & $\begin{array}{l}\text { OCCISCO records the person's primary occupation, coded } \\
\text { according to the major categories in the International Standard } \\
\text { Classification of Occupations (ISCO) scheme for } 1988 .\end{array}$ & $\begin{array}{l}\text { Person/ } \\
1 \text { - Legislator } \\
2 \text { - Professional } \\
3 \text { - Technician } \\
4 \text { - Clerks } \\
5 \text { - Service Workers } \\
6 \text { - Skilled workers } \\
7 \text { - Crafts } \\
8 \text { - Operators } \\
9 \text { - Elementary workers } \\
10 \text { - Armed Forces } \\
11 \text { - Others }\end{array}$ \\
\hline
\end{tabular}

The dependent variable, NCHILD, is the number of children in the household who are less than 16 years of age. The independent variables Poploc, Momloc are included so as to capture the role and importance of parents in providing for the family and also to gather information on the relationships of the family members to the household head. The group of independent variables Poploc, Momloc and Marst are used as proxies of the intergenerational relationships. The demographic variables in this data will be urban, ethnicity, and religion. The variables Ownership, Education and Occupation are the proxies of the socio-economic status (relative income) of the household, since this particular dataset does not include other variables related to the household's social status.

According to Olfa \& Lahga (1990), to resolve the problem of relative income (Becker \& Lewis, 1973; and Becker, 1981), they use indirect measures, such as those used by Santos \& Covas (2000). These measures 
include the couple's education, work status, and place of residence, which can be used as indirect measures of the resources available to the couple and the cost of raising a child. Education will also reflect the potential wage rates and income forgone (opportunity cost) while raising children. For the analysis of the model, the selected sample includes females of child-bearing age (18 to 49) after referring to the selected studies that are based on fertility in developed and underdeveloped countries. Other studies use age parameters as follows: Schultz (2005) and Omariba (2005), child-bearing age of 15-19, in Kenya; Ueda (2007), child-bearing age 20-50, in Japan; and Bhaumik \& Nugent (2011), child-bearing age of 18-45, in Germany. According to Malaysia Family Law, women can be married at the age of 18 , with parental consent.

This study uses both Poisson and negative binomial models to estimate and compare the results. . In the Poisson model, the probability that $\mathrm{N}_{\mathrm{i}}$ equals $\mathrm{n}$ is given by

$$
\operatorname{Pr}\left(N_{i}=n\right)=\frac{e^{-\lambda_{i}} \lambda_{i}^{n}}{n !},
$$

where $\mathrm{N}_{\mathrm{i}}$ is a non-negative integer, and $\lambda_{\mathrm{i}}$ is the expectation (and also the variance) of the random variable, $\mathrm{N}_{\mathrm{i}}$. To introduce the regressors, $\lambda_{i}$ is specified in a conventional way: $\lambda_{i}=\exp \left(b_{0}+X_{i} \beta\right)$, where $\beta$ is a coefficient vector and $b_{0}$ can be estimated by substituting for $\lambda_{\mathrm{i}}$ in the above equation and by applying the maximum likelihood estimation method.

Negative binomial regression models do not assume an equal mean and variance and, in particular, they correct for over-dispersion in the data, which occurs when the variance is greater than the conditional mean (Osgood, 2000; Paternoster \& Brame, 1997).

$$
\operatorname{Pr}(X=k)=\left(\frac{r}{r+m}\right)^{r} \frac{\Gamma(r+k)}{k ! \Gamma(r)}\left(\frac{m}{r+m}\right)^{k} \text { for } k=0,1,2, \ldots
$$

The variance can then be written as $m+\frac{m^{2}}{r}$, and the parameter $r$ is referred to as the "dispersion parameter," the "shape parameter", the "clustering coefficient," or the "heterogeneity" or "aggregation" parameter.

\section{Findings and Discussion}

Choosing between the Poisson and the negative binomial regression models depends on the nature of the distribution of the dependent variable. The Pearson goodness-of-fit results indicate that the distribution of the number of children significantly differs for a Poisson distribution, according to the $\mathrm{p}$ value of 0.000 ("Prob.chi2"), which falls below the standard threshold of 0.05 . Therefore, the negative binomial regression is more appropriate for this particular data set. The likelihood-ratio test of alpha $=0$ : $\operatorname{chibar} 2(01)=1.1 \mathrm{e}+04$ Prob $>=$ chibar $2=0.000$ shows that the dispersion parameter is equal to zero and the response variable is over-dispersed and not sufficiently described by the simpler Poisson distribution. The results for each of the factors that are assumed to be directly related to fertility decisions are as follows:

The intergenerational relationship: In the estimated Poisson and negative binomial models, the factors on the intergenerational relationship are highly significant (Table 3). However, the negative coefficient for "mother present in the household" does not affect the decision of whether or not to have children. The "marital status" coefficient variable is positive and significant, probably due to the fact that Muslims are the majority in Malaysia, and in order to have children, a Muslim couple must be married.

The relative-income effect: For the relative-income effect, only "home ownership" shows a positive sign and a significant impact on fertility. "Education level" and "occupation" both show a negative sign, but for occupation it is negative and not significant. These indicate that females who have a high-paying and who are educated prefer to have fewer children, and lean more towards the quality of children. As for home ownership, this indicates whether or not the family has a secure home; only then do they decide to have more children.

Opportunity cost: The estimated coefficient for education, which is a proxy for the negative opportunity cost for a woman, is a cost that becomes larger as the education level increases. This result indicates that as the opportunity cost of raising children increases, households prefer to have fewer children. This finding supports the neoclassical theory of the demand for children (Becker, 1981; Becker \& Lewis, 1973).

Socio-demographic factors: As for "urban" (negative coefficient and significant), this indicates that rural women are likely to have more children. As for "child-bearing age," as women mature and are ready for more children, the sign is positive and significant. For the variable "religion," this factor shows all positive signs, which indicates that religion is one of influencing factors of fertility (McQuillan, 2004). 
The other option to evaluating this model is to analyze the effect of the independent variable on the dependent variable through the incidence rate ratio (IRR). The IRR represents the change in the dependent variable, in terms of a percentage increase or decrease, with the precise percentage determined by the amount the IRR either above or below 1. The IRR for ownership, marital status and child-bearing age suggests that the number of children will increase by approximately $(16 x 0.6) 9.6 \%, 0.7 \%, 0.4 \%$, respectively.

Table 5. Specification results for Poisson regression and negative binomial regression

\begin{tabular}{lllllll}
\hline \multicolumn{1}{c}{ Variable } & Poisson & Std Error & z value & NB & Std Error & z value \\
\hline Constant & -2.63979 & 0.06971 & -37.87 & -2.92940 & 0.07235 & -40.49 \\
URBAN & -0.08048 & 0.004511 & -17.84 & -0.07903 & 0.69200 & -13.87 \\
OWNRSHP & 2.86287 & 0.067938 & 42.14 & 2.80993 & 0.06920 & 40.61 \\
MOMLOC & -1.31205 & 0.014688 & -89.33 & -1.26498 & 0.01590 & -79.55 \\
POPLOC & -1.13477 & 0.025834 & -43.93 & -1.10405 & 0.02822 & -39.12 \\
MARST & 0.37584 & 0.003810 & 98.56 & 0.53688 & 0.00634 & 84.61 \\
RELIG & 0.01204 & 0.001500 & 8.01 & 0.01300 & 0.00190 & 6.83 \\
OCCISCO & -0.00180 & 0.000932 & -1.94 & -0.00205 & 0.00117 & -1.74 \\
Edugroup & -0.06252 & 0.002372 & -26.35 & -0.06099 & 0.00298 & -20.44 \\
Ethnicgroup & -0.08981 & 0.003341 & -26.88 & -0.08651 & 0.00409 & -21.11 \\
Female & -0.27669 & 0.004453 & -62.13 & -0.28747 & 0.00556 & -51.63 \\
AgeCb & 0.35846 & 0.005171 & 69.32 & 0.35397 & 0.00641 & 55.14 \\
\hline Log likelihood $=-227097.29$ & & & Log likelihood $=-221588.6$ & \\
Pseudo R2 = 0.0936. Prob $>$ chi2 $=0.0000$ & & & Pseudo R2 $=0.0679$, Prob $>$ chi2 $=0.000$ \\
No. of observation 123280 & & & & & \\
\hline
\end{tabular}

\section{Conclusion}

This study has developed an empirical model that explains the determinants of household fertility decisions in Malaysia. The empirical results show a negative relationship between the number of children and social status (ownership, education, and socio-economic status), implying that households prefer the quality of children to the quantity of children. On the socio-economic and socio-demographic factors, home ownership, age, and marital status positively affect the number of children. The empirical results presented in this study support the neo-classical theory of fertility and are consistent with fertility studies of many other countries. These findings have important empirical implications for Malaysia, where the declining fertility rate will have an impact on the country's future aspirations of attaining a strong reliable domestic economy and the reallocation of women's time towards work and having a child.

\section{References}

Angrist, J., Lavy, V., \& Schlosser, A. (2010). Multiple Experiments for the Causal Link between the Quantity and Quality of Children. Journal of Labor Economics, 28(4), 773-824. http://dx.doi.org/10.1086/653830

Becker, G. S. (1960). An economic analysis of fertility. In Demographic and Economic Change in Developed Countries. Universities National Bureau Conference Series. No.11. Princeton, N.J: Princeton University Press. Retrieved from http://www.nber.org/chapters/c2387.pdf

Becker, G. S. (1981). A treatise on the family. Cambridge, MA: Harvard University Press. Retrieved from www.hup.harvard.edu/catalog.php?isbn=9780674906990

Becker, G. S., \& Lewis, H. G. (1973). On the interaction between quantity and quality of children. Journal of Political Economy, 81, 279-288. https://doi.org/10.1086/260166

Bhaumick, S. K., \& Nuget, B. J. (2011). Real options and demographic decisions: Empirical evidence from East and West Germany. Applied Economics. New York: Routledge.

Caldwell, J., Caldwell, P., \& McDonald, P. (2002). Policy Responses to Low Fertility and its Consequences: A Global Survey. Journal of Population Research, 19(1), 1-24. https://doi.org/10.1007/BF03031966

Cameron, A. C., \& Trivedi, P. K. (1998). Regression analysis of count data. New York: Cambridge University Press. https://doi.org/10.1017/cbo9780511814365

Del Boca, D., Locatelli, M., \& Vuri, D. (2003). What Child Care Works Best? Evidence from Italy. WP ChilD 2003. Retrieved from http://www.child-centre.it

Department of Statistics Malaysia. (2013). Population Projection Malaysia. 
Ermish, J. (1986). Impacts of Policy Actions on the Family and Household. Journal of Public Policy, 6(3), 297-318. https://doi.org/10.1017/S0143814X00004049

Ermish, J. (1988). The Econometrics Analysis of Birth Rate Dynamics in Britain. The Journal of Human Resources, 23(4), 563-576. https://doi.org/10.2307/145814

Herzer, D., Vollmer, S., \& Strulik, H. (2010). The long-run determinants of fertility: One century of demographic change 1900-1999. Discussion Paper. University of Hannover. Retrieved from https://cdn1.sph.harvard.edu/wp-content/uploads/sites/1288/2013/10/PGDA_WP_63.pdf

Hondroyiannis, G. (2004). Modeling household fertility decisions in Greece. The Social Science Journal, 41, 477-483. https://doi.org/10.1016/j.soscij.2004.04.003

Lee, R., \& Mason, A. (2010). Fertility, Human Capital, and Economic Growth over the Demographic Transition. European Journal of Population, 26(2), 159-182. http://doi.org/10.1007/s10680-009-9186-x

McQuillan, K. (2004). When does religion influence fertility? Population and Development Review, 30(1). Population Council Source. http://onlinelibrary.wiley.com/doi/10.1111/j.1728-4457.2004.00002.x

Minnesota Population Center, Integrated Public Use Microdata Series, International: Version 6.2 [Machine-readable database]. Minneapolis: University of Minnesota, 201.

Morgan, S. P. (2003). Is low fertility a twenty-first-century demographic crisis? Demography, 40, 589-604. https://doi.org/10.1353/dem.2003.0037

Olfa, F., \& Lahga, A. El. (n. d.). A Socioeconomic Analysis of Fertility Determinants A Socioeconomic Analysis of Fertility Determinants Abstract.

Omariba, D. W. R. (2005). Women's Educational Attainment and Intergenerational Patterns of Fertility Behaviour in Kenya. Journal of Biosocial Science, 38, 449-479. https://doi.org/10.1017/S0021932005026489

Osgood, D. W. (2000). Poisson-based Regression Analysis of Aggregate Crime Rates. Journal of Quantitative Criminology, 16, 21-44. https://doi.org/10.1023/A:1007521427059

Paternoster, R., \& Brame, R. (1997). Multiple routes to delinguency? A test of Developmental and General Theories of Crime. Criminology, 35, 45-84. https://doi.org/10.1111/j.1745-9125.1997.tb00870.x

Santos, S. J. M. C., \& Covas, F. (2000). A modified hurdle model for completed fertility. Journal of Population Economics, 13, 173-188. https://doi.org/10.1007/s001480050132

Schultz, T. P. (2005). Fertility and Income. Center discussion paper//Economic Growth Center, No.925. https://doi.org/10.2139/ssrn.838227

Shapiro, D., \& Mott, F. L. (1994). Long-Term Employment and Earnings of Women in Relation to Employment Behavior Surrounding the First Birth. The Journal of Human Resources, 29(2)(Spring), 248-274. https://doi.org/10.2307/146098

Ueda, A. (2007). A Dynamic Decision Model of Marriage, Childbearing and Labour Force Participation of Women in Japan. The Japanese Economic Review, 58(4). https://doi.org/10.1111/j.1468-5876.2007.00432.x

Utomo, I. W., \& Firmanto, A. (2007). Women's Fetility Decision-Making in Indonesia: The Meaning of the Responses of Numeric vs Non-Numeric Family-Size Desires. Austarlian Demographic and Social Research Institute. Retrieved from http://www.jstor.org/stable/2947904

Winkelmann, R. (1995). Duration dependence and dispersion in count-data models. Journal of Business and Economics Statistics, 13, 467-474. https://doi.org/10.1080/07350015.1995.10524620

Winkelmann, R. (2003). Econometric Analysis of Count Data (4th ed.). Heidelberg: Springer Verlag. https://doi.org/10.1007/978-3-540-24728-9

\section{Copyrights}

Copyright for this article is retained by the author(s), with first publication rights granted to the journal.

This is an open-access article distributed under the terms and conditions of the Creative Commons Attribution license (http://creativecommons.org/licenses/by/4.0/). 